\title{
Climate Change Impact on Water Resources at the Transboundary Level in West Africa: The Cases of the Senegal, Niger and Volta Basins
}

\author{
Lekan Oyebande and Shakirudeen Odunuga*
}

*Department of Geography, University of Lagos. Nigeria

\begin{abstract}
The series of droughts of the past three decades that affected the Sudano-Sahelian zone of West Africa, particularly Niger, Volta and Senegal basins impacted the water resources, ecosystems and the fragile economies of at least 13 of the 16 countries of the region. Declining rainfall, highly variable in time and space has resulted in more than proportionate decrease in river discharges, and declining level of freshwater bodies. This situation translated into falling groundwater levels and accelerated desertification process, hence major crises of food insecurity and massive migration, which often leads to conflicts. The challenges and uncertainties associated with the impacts of future climate changes on water resources in West Africa are further compounded by many other factors, including regional demographic factors, nonexisting or inadequate water policies, inefficient management strategies and lack of reliable and adequate data. This paper synthesizes the state of art research regarding climate change impact on water resources in West Africa economies of Senegal, Niger and Volta Basins while also making prescriptions on what can be done in terms of adaptation strategies, rather than mitigation, to reduce the severity of the expected impacts on the already stressed and poverty-stricken economies of West Africa,
\end{abstract}

Keywords: West africa and climate change.

\section{INTRODUCTION}

The countries included in western Africa undeniably constitute a more or less homogenous unit. First of all in relation to geology and physiography, secondly in relation to population characteristics, elements of culture and history, and finally in relation to economy and social conditions characterizing all the countries of the region as developing countries. Several characteristics recur from one country to another some of these include a strong demographic growth, a young population, fast and uncontrolled urbanization rates, national economies dominated by the agricultural sector, slow human resources development, poorly developed access to drinking water and insufficient or non-existing sanitation systems. The demand for freshwater comes mainly from agriculture, followed by domestic, industrial and hydroelectric power demands. There are a large number of river basins in Western Africa, 11 of which are transboundary. There are also three major transboundary groundwater basins. This transboundary peculiarly imparts to the countries of the subregion high water dependency ratio.

The climates in the region range from humid equatorial at the coast to semi-arid and arid in the northern Sahelian countries. Rainfall varies from less than $200 \mathrm{~mm} / \mathrm{yr}$ in the arid zone to more than $1000 \mathrm{~mm} / \mathrm{yr}$ in the equatorial/tropical zone. Inter-annual variation is very high. All over the Sahel, a decrease in rainfall over the last four decades, particularly 1970-2000 presents a decrease in the number of rainfall events, except in the extreme south. The potential evapotranspiration amounts to $1300 \mathrm{~mm} / \mathrm{yr}$ in the humid regions and

*Address correspondence to this author at the Department of Geography, University of Lagos, Nigeria; Tel: 234-8037232665;

E-mail:odushak@yahoo.co.uk increases to about $2000 \mathrm{~mm} / \mathrm{yr}$ around latitude $20^{\circ} \mathrm{N}$. The actual evaporation is higher in the region of higher rainfall and decreases to nearly zero in the region of minimum rainfall in the Sahara Desert. The potential and actual evapotranspiration follow the same pattern as the actual evaporation. Generally, the annual surplus of water decreases northward and rapidly turns into an annual deficit in the region between $10^{\circ} \mathrm{N}$ and $20^{\circ} \mathrm{N}$ and becomes more acute in the Sahara (lat. $20^{\circ} \mathrm{N}$ and $30^{\circ} \mathrm{N}$ ).

Surface water resources in the region are rivers, lakes and wetlands. The major rivers flow over more than one hydro(geo)logical region and are transboundary, making it imperative for the riparian states to cooperate in water resource management. River runoff decreases northwards. Water is most abundant between August and October, when 40 to $70 \%$ of the annual runoff occurs. Southward, in the subhumid parts of the tropical zone, five to six months account for $80 \%$ of the annual runoff whereas in the humid zones there is a more even distribution of runoff during the year with two peaks being observed [1]; about $80 \%$ of the mean annual runoff occurs within eight to nine months.

The sub-Saharan drought of the early 1970s in western Africa had serious consequences on the water resources of the region. Analysis of the monthly rainfall data for the whole region by [2] shows that the dry period was characterized by a decrease in the number of rainy events, while the mean storm rainfall varied little. A deficit of 10 to $30 \%$ in the rainfall generally leads to a deficit of 20 to $60 \%$ in river discharge. The Niger River, the largest river in western Africa, dried up for several weeks at Malanville in the Benin Republic in 1985. This was a consequence of a one-year lag of lowest rainfall and runoff (1984) recorded since the beginning of the century in the upper basin. However, Model 
projections of rainfall over West Africa are inconsistent, with some simulations suggesting that the region will become drier, and others predicting increases in rainfall over the $21 \mathrm{st}$ century [3]. This paper however, synthesis the state of art research regarding climate change impact on water resources in West Africa sub-region using the cases of three major basins of Senegal, Niger and Volta basins.

\section{The Senegal Basin}

The Senegal River has its main source in the FoutaDjalon Mountains in Guinea and provides water to the semiarid parts of Mali, Senegal and Mauritania. The basin has a total area of $\sim 483000 \mathrm{~km}^{2}$ and the river course is $1800 \mathrm{~km}$ long (Fig. 1). Mauritania has the largest area of the basin with $50 \%$, followed by Mali with $35 \%$, Senegal with $8 \%$, and Guinea with $7 \%$.

As in the rest of western Africa, rainfall in the Senegal River Basin is influenced by the north-south migration of the Inter-Tropical Convergence Zone (ITCZ), and is characterised by inter-annual variation (coefficient of irregularity: $\mathrm{k}=1.5$ to 2). A large north-south gradient is present, with the highest rainfall in the Fouta-Djalon area (up to $2000 \mathrm{~mm} / \mathrm{yr}$ ) and the lowest towards the extreme north (less than 200 $\mathrm{mm} / \mathrm{yr}$ ). Since the $1970 \mathrm{~s}$, the $400 \mathrm{~mm}$ isohyet has shifted southward over a distance of $\sim 100 \mathrm{~km}$, thereby jeopardising rain-fed agriculture over large areas. The degree of aridity, expressed as the ratio between annual precipitation and potential evapotranspiration, is shown in Table $\mathbf{1}$ for different periods at different basin locations. Aridity [4] was prevalent throughout the whole period between 1960 and 1996 and was highest (lowest ratio) in Podor in 1983.

Table 1 shows that there has been a long-lasting drought in the Senegal River Basin for more than 30 years. As drought persists, the state of aridity increases in the sahelian zone of Senegal basin. The decrease in rainfall has led to a corresponding decrease in river flow, e.g. a $20 \%$ decrease in rainfall resulting in a $30-40 \%$ decrease in available water resources. The drought has reduced rain-fed agriculture, decreased the seasonal flooding of wetlands, limited economic development, and in the overall, enhanced poverty. The key hydrological changes that have occurred in the basin are closely linked to the displacement of the isohyets to the south and the increase in evapotranspiration.

\section{Climate Change Impact on Water Resources in the Senegal}

Water is one of several current and critical issues facing the basin region because of its unequal natural geographic

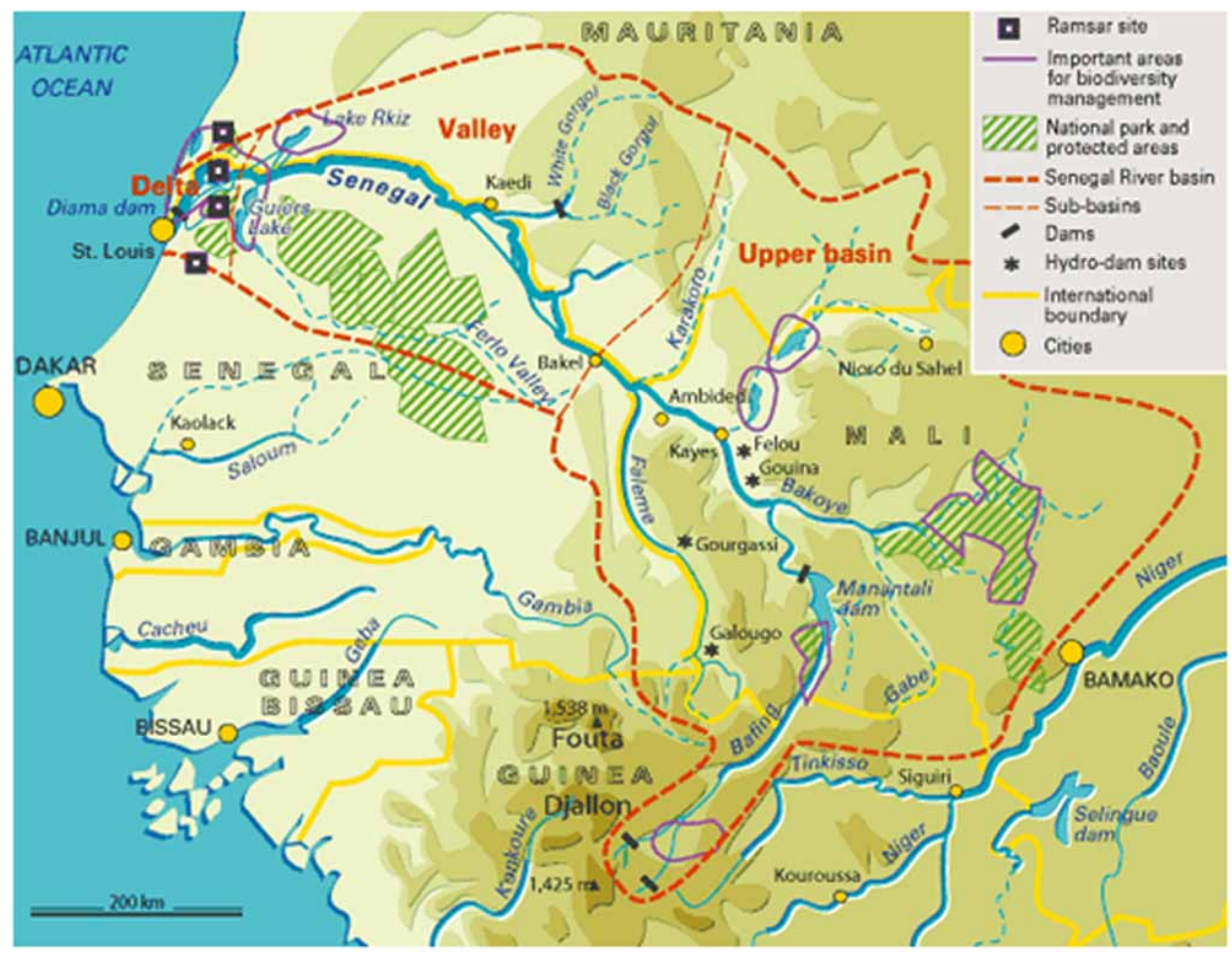

Fig. (1). Senegal River Basin.

Table 1. Aridity in the Senegal River Basin

\begin{tabular}{|c|c|c|c|c|c|}
\hline Location & $\mathbf{1 9 6 1 - 1 9 7 0}$ & $\mathbf{1 9 7 1 - 1 9 8 0}$ & $\mathbf{1 9 8 1 - 1 9 9 0}$ & $\mathbf{1 9 9 1 - 1 9 9 6}$ & 0.26 \\
\hline \hline Bakel & 0.28 & 0.25 & 0.24 & 0.17 & 0.25 \\
\hline Matam & 0.24 & 0.15 & 0.18 & 0.09 & 0.10 \\
\hline Podor & 0.13 & 0.09 & 0.08 & 0.19 \\
\hline
\end{tabular}

Arid: $<0.25$; semi-arid: $0.25-0.45$ 
distribution and accessibility, and unsustainable water use. Climate change scenarios predict reduced rainfall and increases in evaporation in sudano-sahelian zones of Africa [5] where the substantial part of the basin falls. Within the basin, the impact of an intensification of the West African Monsoon (WAM) is likely to have the greatest impact especially around Senegal and Mauritania. While additional rainfall in these regions may be beneficial in some respects, it might also have negative impacts such as more frequent flash flooding and locust infestations, as well as inappropriate agricultural expansion into historically marginal areas such as occurred throughout the Sahel in the 1950s. Such land use abuse had resulted in dramatic increases in regional vulnerability to climate variability and change [6]. If this prediction is combined with the existing high rate of deforestation and degradation of the ecosystem, it could have serious consequences on soil erosion and consequently on agricultural production and food self-sufficiency. It will also impose additional pressure on water availability and accessibility. Recently a number of modelling studies have explicitly addressed the impacts on increased GHG concentrations on West African rainfall, with and without representing vegetation-atmosphere feedbacks. These studies suggest that increases in atmospheric GHG concentrations (from current elevated levels up to about $550 \mathrm{ppm}$ ) may make the West African rainfall regime more robust, and droughts less frequent and persistent [7]. A number of these studies equally shows the strengthening of the West African Monsoon (WAM) and a penetration of rainfall and vegetation further north, resulting in a "greening" of the many parts of the Senegal, Gambia, Great and Little scarcies [8-10].

These results are consistent with recent trends in the Sahel, where rainfall and vegetation cover have increased in many areas relative to the dry period lasting from the early 1970s until the late 1990s [11, 12]. However, other speculative studies have also noted that over the coming century or longer, it is possible that the region will experience alternating periods of humidity and aridity as atmospheric GHG concentrations increase. Although this scenario remains highly speculative at present, a number of other uncertainties, such as the role of ENSO also remain so. Even if predictions of a strengthened monsoon prove accurate, rainfall within the basin is likely to remain highly variable both temporally and spatially beyond 2030 .

Changes in the rainfall regime within the basin may also be associated with shifts in seasonality. At present it is unclear whether any greening of the basin zone will represent additional regional rainfall or will facilitate a redistribution of rainfall. More recent study has supported increase in rainfall after the long drought. The rainy season across the basin was characterized by enhanced rainfall activity, with amounts about $15 \%$ above the long term climatological mean for the period 1950- 2005. However, this represents a $60 \%$ increase in rainfall relative to the most recent 30 years climatological mean for 1971-2000. This marks a sharp contrast from the long term drying trend that started in the early 1970s. Over the past 3 years, the coupled ocean - atmosphere system has been quite similar to observed conditions during the $50 \mathrm{~s}$ and $60 \mathrm{~s}$. It can therefore be surmised that the senegal will witness rainfall increase till about 2030 .

Stream flow modifications have been observed in the Senegal basin and surrounding areas. The main consequence is the problem of water resources availability, in terms of quantity or quality. The major causes of stream flow modification in the region relate primarily to climatic change, population growth and its implications, problems in implementation of appropriate water and environmental management, and insufficiencies in technology and financial resources. With respect to direct increase or decrease in rainfall, $1 \%$ change in rainfall can translate to $3 \%$ change in stream flow on Gambia. Climate change alone could cause $50 \%$ in runoff in the region [5]. The southern Senegal basin where the Great and Little scarcies are flowing more or less perennially will generate high runoff with less variability while the projected runoff of the sahelian zone of Gambia and Senegal will exhibit high variability. In the scenario that projected increase rainfall [13], stream flow within the Senegal basin will by 2030 be more than double and this will create serious challenges in terms of control, uses and prevention of diseases.

Presently, the annual discharge of the Senegal basin ranges between a minimum of $6.9 \mathrm{bm}^{3}$ and a maximum of $41.5 \mathrm{bm}^{3}$ with an average of about 30 billion $\mathrm{m}^{3}\left(\mathrm{bm}^{3}\right)$. Data availability for aquifers in the region is, however, quite limited. A decline has been linked to the long dry periods (more than 30 years) and overextraction of groundwater for irrigation and urban water supply [14]. The Sengal basin Water stress is $5800 \mathrm{~m}^{3}$ person $^{-1}$ year $^{-1}$. Table 2 shows the total annual renewable water resources for some countries within the basin. On average, agriculture accounts for more than $85 \%$ of the water withdrawals in the Basin. Basin Population is about 3.5 Million inhabitants with annual Growth Rate 3\%

The planned exploitation of the basin's irrigation potential of 375,000 ha, including 240,000 ha in Senegal, 120,000 ha in Mauritania, and 9,000 ha in Mali. However, agricultural productivity is relatively low, with total productivity

Table 2. Renewable Water Resources and Freshwater Withdrawal in Some Countries of Senegal Basin

\begin{tabular}{|c|c|c|c|c|c|}
\hline Country & Renewable water resources $\left(\mathrm{km}^{3}\right.$ year $\left.{ }^{-1}\right)$ & Total fresh water withdrawal $\left(\mathrm{km}^{3}\right.$ year $\left.{ }^{-1}\right)$ & \multicolumn{3}{|c|}{ Use $(\%)$} \\
\hline Guinea & 226 & 0.74 & 10 & 3 & 87 \\
\hline Mauritania & 11.4 & 1.63 & 6 & 2 & 92 \\
\hline Senegal & 39.4 & 1.36 & 5 & 3 & 92 \\
\hline
\end{tabular}

Source [15] 
satisfying only a small portion (30\% in Mauritania and $15 \%$ for Senegal) of the national requirements [15]. Using the Palmer Drought Severity Index (PDSI) for 1900 to 2002, [16] observed a drying trend over the sahelian region of the Senegal basin. If this trend continues, with the attendant increasing demand for water especially in the agricultural and domestic sectors due to population increase, severe drought should be expected in the near future.

However, climate change in the basin is expected to be accompanied by greater variability in rainfall and temperatures, thereby creating an uncertain situation that would need complex analysis for diagnoses. High variability in precipitation and temperature would give rise to frequent changes in agro climatic characteristics and increase variability in yields of crops in the different ecological zones Consequently, this situation will seriously impact on GDP of some of the countries within the basin. Climate change will also have considerable impacts on agricultural systems and ultimately affecting crop calendar and lengths of growing periods. Extreme events such as heavy downpours and droughts will reduce crop yields within the basin because excesses or deficits of water will have negative impacts on plant growth.

In summary, the climatic future of the Senegal basin is uncertain and imperatively no single scenario can be provided at present. While temperature is almost certain to rise, rainfall may increase or decrease.

Adaptation planning might be based on a "worst case" scenario incorporating the following assumptions:

* Increases in mean surface temperature of up to $0.5^{\circ} \mathrm{C}$ per decade, with increased evapotranspiration and crop water requirements.

* Increased rainfall variability and intensity resulting in increases in continental runoff and sediment transport, but less predictability in the timing of rainfall.
The challenges of analysing climate change impact on water resources for the Senegal Basins range from high level of uncertainty and lack of knowledge of predicting the future climate changes and their impacts within the basin region, which is hindering sound water management planning. Present hot spots are mainly in the areas where dams and large reservoirs have been developed. These include; Manantali, and Diama (Senegal River). Public awareness and education is also needed to prepare stakeholders for the worst while hoping for the best. There is the need for more regorious studies to be done to apply appropriate regional scale models to aid the prediction of climate change in the coming decades

Worsened water shortage arising from further reduction in rainfall and raised temperatures are major risks in the whole region. The challenges of the current water situation of the region have been examined in some details. What may be expected is an intensification of the present situation so that it is taken beyond the endurance of humans, fauna and flora. This could be further aggravated by lack of IWRM practices to improve the efficiency of use of the dwindling water resources.

\section{The Niger and Volta}

The Niger River Basin covers 2.27 million $\mathrm{km}^{2}$, with the active drainage area comprising less than $50 \%$ of the total. At $4200 \mathrm{~km}$ in length, the Niger is the third longest river in Africa and the world's ninth largest river system. The basin is shared among 10 countries: Nigeria (27\%), Mali (26\%), Niger (24\%), Algeria (8\%), and Benin, Burkina Faso, Cameroon, Chad, Cote d'Ivoire and Guinea (each $<5 \%$ ). The Niger River Basin is generally considered to be one of the two river basins (with the Volta) most affected by freshwater shortages. Fig. (2) shows the Niger basin in West Africa.

The Volta River Basin on the other hand covers an estimated area of $400000 \mathrm{~km}^{2}$. The basin stretches from ap-

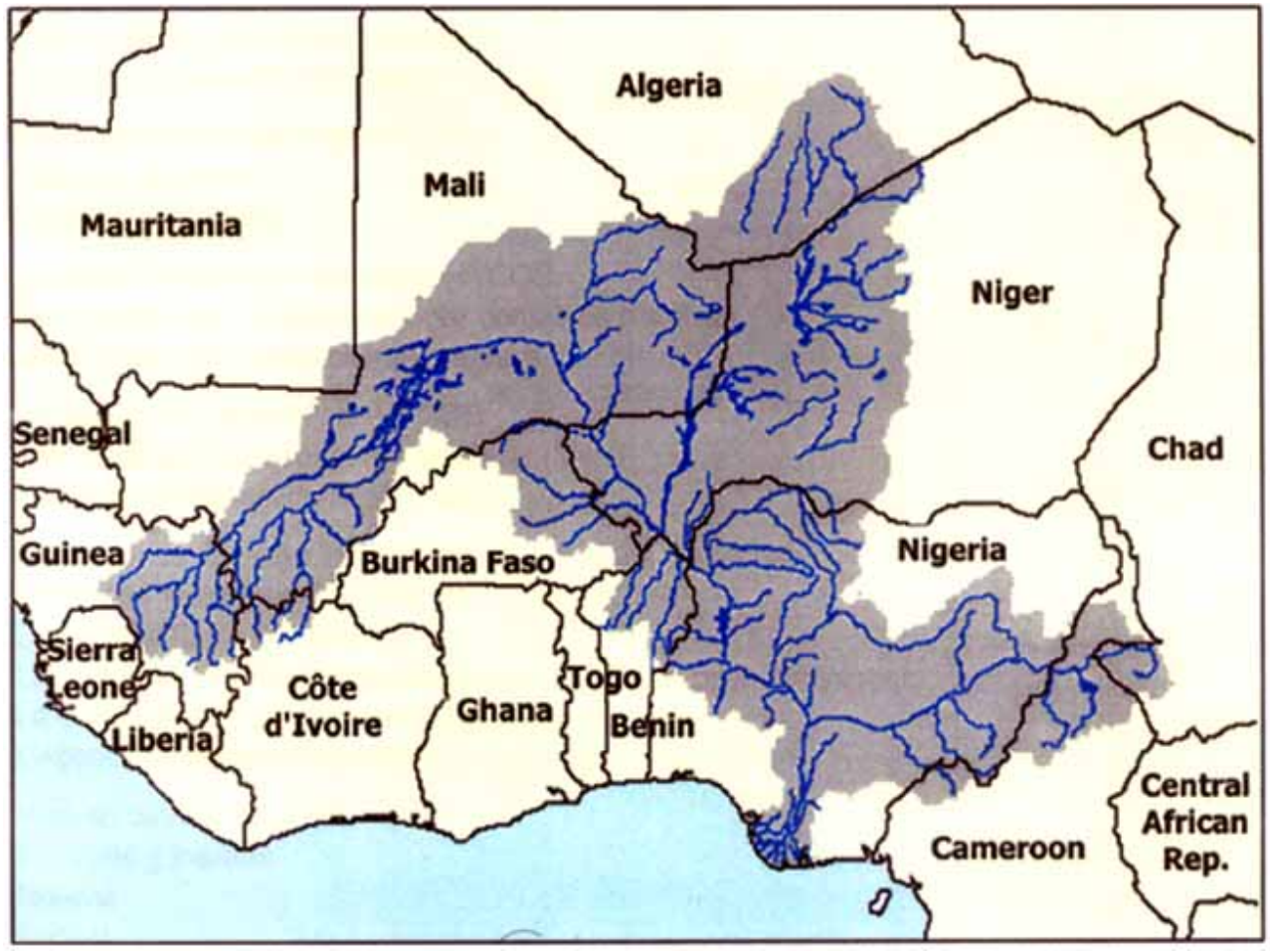

Fig. (2). The Niger basin in West African. 
proximately latitude $5^{0} 30^{\prime} \mathrm{N}$ in Ghana to $14^{0} 30^{\prime} \mathrm{N}$ in Mali. The widest stretch is from approximately longitude $5^{0} 30^{\prime} \mathrm{W}$ to $2^{0} 00^{\prime} \mathrm{E}$ but the basin becomes narrower towards the coast of the Gulf of Guinea. The Volta Basin spreads to over six western African countries (43\% in Burkina Faso, $42 \%$ in Ghana, and $15 \%$ in Togo, Benin, Cote d'Ivoire and Mali). Fig. (3) shows the Volta River Basin.

Precipitation is very variable spatially and temporarily in the basins (Niger and Volta). Precipitation amounts from one year to another shows wide variations, as it is within the year. Apart from the variability of the annual and seasonal rainfalls, the extremes of precipitation occur which results in floods and droughts at different times and sometimes within the same period. For instance in 1984 which represents perhaps the driest year in the Niger basin also experienced the heaviest rain in more than 30 years.

The Niger and Volta flow over more than one hydro(geo)logical region and are transboundary, making them imperative for the riparian states to cooperate in water resource management. River runoff decreases northwards. Water is most abundant between August and October, when 40 to $70 \%$ of the annual runoff occurs. Southward, in the subhumid parts of the tropical zone, five to six months account for $80 \%$ of the annual runoff whereas in the humid zones of the basins there is a more even distribution of runoff during the year with two peaks being observed [1]; about $80 \%$ of the mean annual runoff occurs within eight to nine months. River flows respond quickly to the rainfall pattern though with a multiplier factor of 1.5 to 3.0 .

In general, hydrological processes and water resources are characterized by extreme variability both over space and time. Some of the countries (eg Nigeria and Ghana) are well endowed with water resources while others such as Burkina Faso face serious water scarcity problems. And while drought is a common feature of the Sahelian zone since the 1970s, floods periodically affect the coastal belt. In general, the region is characterized by, first, a high degree of vulnerability. This is as a result of natural climatic variation which combines with the increase in unpredictability of precipitation variability. Increase in demand from the rapidly growing population is another characteristic of the region.

\section{Climate Change Impact on Water Resources in the Niger and Volta Basins}

The climate of the Niger and Volta basins, particularly in the Sahelian part of the Burkina Faso, Ghana and Nigeria

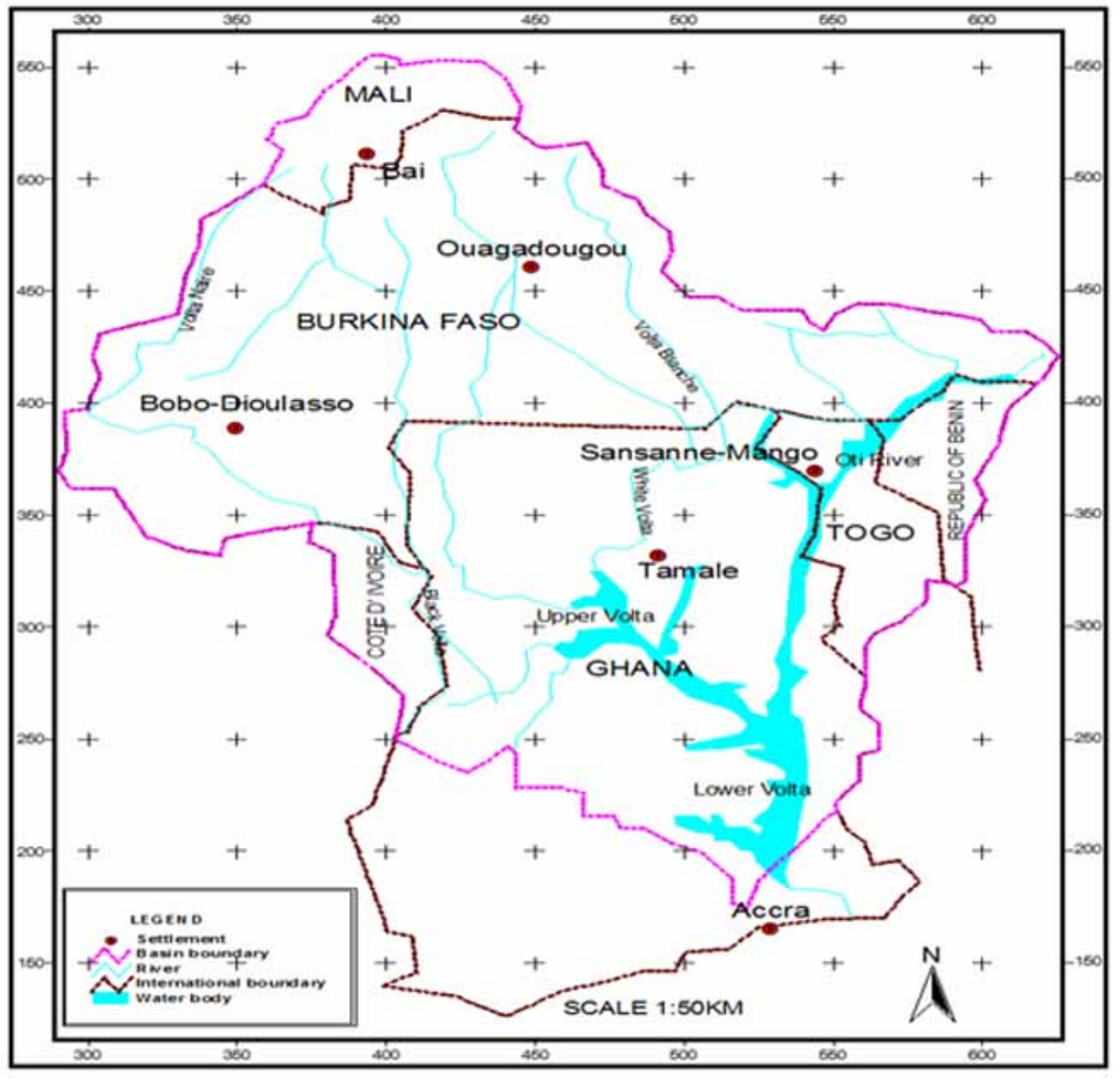

Fig. (3). Volta River Basin. 
(Niger basin), has been undergoing changes of significant magnitude, particularly since the early 1970 's. The region has experienced a marked decline in rainfall and hydrometric series around 1968-1972, with 1970 as a transitional year. The decline in average rainfall, before and after 1970, ranges from $15 \%$ to over $30 \%$ depending on the area in Niger and Volta basins. This situation resulted in a $200-\mathrm{km}$ southward shift in isohyets (Fig. 4). If this situation continues, it could in turn accelerate desertification, which will in turn contribute to the persistence of drought. This cycle is likely to play a part in increased desert encroachment. Analysis of the monthly rainfall data for the whole region by [2] shows that the dry period was characterized by a decrease in the number of rainy events, while the mean storm rainfall varied little. Within the basins, a deficit of 10 to $30 \%$ in the rainfall generally leads to a deficit of 30 to $60 \%$ in river discharge [15].

Average discharge in the region's major rivers underwent concomitant and highly pronounced variations compared to rainfall values. An average decline in the range of $40-60 \%$ in discharge has also been observed since the early 70's [17]. The Niger River, the largest river in western Africa, dried up for several weeks at Malanville in the Benin Republic in 1985. This was a consequence of a one-year lag of lowest rainfall and runoff (1984) recorded since the beginning of the century in the upper basin.

\section{Projection of Temperatures}

The report of working group II to the fourth assessment report of the Intergovernmental Panel on Climate Change on Impact Adaptation and Vulnerability [13], noted that from general circulation models (GCMs) and the various downscaling regional climate model (RCMs) the mean, mean maximum and mean minimum temperatures for the region of the Niger and Volta basins as a whole show increasing trends. In general, the temperature shows an increase of about $0.2-0.3^{\circ} \mathrm{C}$ per decade. Projections for the $21^{\text {st }}$ Century in the Savanna and sahel indicate a general increases in minimum temperature for all the months in this zone. These increases may be as high as over $5^{\circ} \mathrm{C}$ for January to less than $3.5^{\circ} \mathrm{C}$ for August [13]. With these increases, the nights are still expected to remain cool and pleasant, with temperatures in the range of $20^{\circ} \mathrm{C}$ to $28^{\circ} \mathrm{C}$. Projections of the mean maximum temperatures in Savannah zone indicate increases in mean monthly temperatures. These increases will raise mean monthly maximum temperatures to a range from $34^{\circ} \mathrm{C}$ to $43^{\circ} \mathrm{C}$. There is hence the possibility of an increase in heat related health problems by 2070 to 2099 time slice [19].

\section{Rainfall Projections}

Even if model simulations are not coherent from one model to the other, with regard to this region which is part of

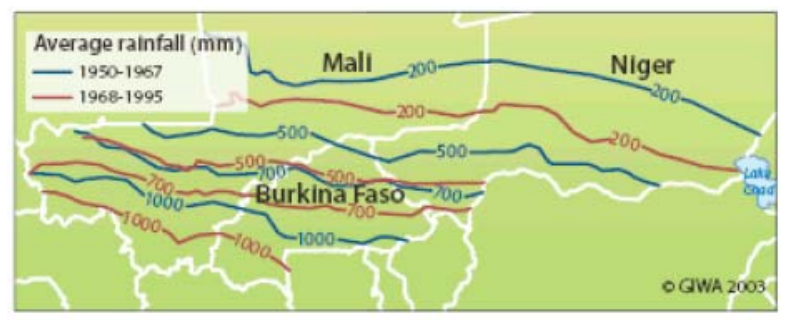

Fig. (4). Average rainfall in the Niger Basin in 1950-1967 and 1968-1995 depicting the southwards move of isohyets Source: [18].
Western Africa, it is to be noted that the evolutions in future rainfall by the majority of the general circulation models (GCMs) are relatively modest, at least compared to the variability of current rainfall. Most climate change scenarios consider a reduction in precipitation, which varies from 0.5 to $40 \%$ with an average of 10 to $20 \%$ for the horizons 2025 [19].

The study done within the framework of the national communication in the various countries predicts a reduction of the annual rainfall from 7 to $24 \%$, compared to the average annual rainfall of 1961 to 1990 [15]. Togo considers very limited variations of precipitation (lower than $1 \%$ ). In addition, some countries took into account a hypothesis of precipitation increase (for example Mali and Burkina Faso). Baseline period conditions indicate an effective rainy season of only four months long in the Sudan zone. Six of the dry season months are rainless. Although the onset of the season is in May in most years, the fields are not sufficiently wet for cropping until June. The rainfall projection for June indicates significant increases, while July, August and September are projected to remain as they are for the baseline period from 1961-1990. In the Sahel zone, although the onset of the rainy season is in May, June in some years may not receive as much rain as to make planning feasible. Rainfall in sufficient amounts occurs only in July and August. Projections for this zone indicates an increase in rainfall for June, July and August up to 2069 followed by a decrease during the final 30 years of the $21^{\text {st }}$ century. The significant increases in the rainfall of June will tend to bring that month more effectively into the planting season [20].

The savannah and Sahel areas of the sub-region would probably have less rainfall, when taken with the temperature increases, would reduce soil moisture availability. Higher evaporation rates from the extended reservoirs of the major dams and greater water requirement per hectare of crop in the major irrigation projects in the region would further decimate available water for all uses and exacerbate the water shortage challenge. Already, these savannah and semiarid areas suffer from seasonal and inter annual climatic variability, and there have been droughts and effective desertification processes, particularly, since the 1960s [20]. This situation may be worsened by the expected decrease in rainfall with greater drought probabilities and more rainfall variability and unreliability. All these would consequently result in reduced soil water availability in rainfed systems and increase the adverse characteristics of the savannah ecosystems, including water and wind erosion, which in turn will affect food and livestock production, fuel availability and the characteristics of human settlements.

\section{Surface and Ground Waters}

Although the forecasts with regard to stream flow and ground water recharge vary at the regional level according to the envisaged changes in precipitation, the majority of climate change scenarios report a decrease in stream flow and groundwater recharge in the arid and semi-arid zones of the sub-region. In general, river flow is expected to decrease in proportions varying between 5 and $34 \%$ according to the time horizon and location.

The increase in discharge observed over some subwatersheds of the Volta River such as the Nakambé, may be 
explained by increased runoff coefficient which is due to the degradation of the vegetative cover and the soil. One can cite the case of the River Niger and its tributaries along its middle course, where important transport of solids was observed in the main riverbed, which consequently tended to silt up the latter as an example of the accelerated erosion.

Furthermore, there is likely to be a lowering of the ground water level following the reduction in their recharge as well as a reduction in the number and size of ponds and watering points. The recharge of the region aquifers has noticeably decreased, as is the case of rainfall, and this is often due to the decline in rainfall and surface runoff. For instance, in the Bani sub-watershed, across the upper reaches of the Niger River in Mali, water tables reached their lowest levels in 1997. The decline in water tables has significant consequences on the depletion coefficients/ base flow (e.g. the Senegal River at Bakel or the Niger River at Koulikoro).

\section{Extreme Events}

There is lack of information to confirm or invalidate the common assumption that a fall in the magnitude of floods in much of the region and their localised increase in the Sahelian areas are solely a consequence of man-made activities. However, the major droughts and a certain number of recent floods of unusual magnitude in the Sahel and in other zones of the region prompt many researchers to expect exacerbated climate extremes in some parts of West Africa. Flows during low seasonal water levels could drop in many areas because of lower groundwater levels and greater evaporation.

\section{Wetlands and Invasive Weeds}

The recorded decline in the discharge of major watercourses has resulted in the significant reduction in surface area of the main natural wetlands. The average area of the Inland Delta of the Niger River decreased from $37,000 \mathrm{~km}^{2}$ in the early 1950 s to about $15,000 \mathrm{~km}^{2}$ in 1990 . The proliferation of floating weeds (the water lettuce, water hyacinth, Typha, etc.) results from the general disruption of the climate in the region. This is particularly due to the reduced flow velocity in watercourses, temperature change as well as the deterioration of water quality. These weeds hinder fishing, navigation, the functioning of irrigation schemes and hydroelectric development. Furthermore, they provide favourable conditions for the multiplication of vectors of water-borne diseases, such as malaria and the outbreak of new diseases (e.g. the Rift Valley fever). They also choke several water bodies of the region, including lakes and wetlands known for their biological diversity of global importance.

\section{Impact on the Coast and Coastal Zone}

The variability of the climate has not spared the coastal areas. Being sensitive to erosion, beaches and dune ridges along the coast show evidence of retreat at variable paces: from $1-2 \mathrm{~m}$, to more than $20-30 \mathrm{~m}$ per annum along the Gulf of Guinea, respectively. An accelerated retreat of the coastline was observed between 1987 and 1991 and resulted in the disintegration of the dune ridges. In the first global analysis of vulnerability to the impacts of sea level rise by IPCC/RSWG in 1990, 8 out of the 50 countries classified as the most vulnerable in the world, are located in West Africa and three of them: Togo $\left(36^{\text {th }}\right)$, Benin $\left(39^{\text {th }}\right)$, and Ghana $\left(46^{\text {th }}\right)$ belong to the Niger and Volta basins.

\section{Increased Frequency and Magnitude of Extreme Events}

Extreme events (devastating floods, droughts and sharp temperature changes) characterize climate change and variability, and seem to occur more frequently in the sub-region. They sometimes entail very high environmental and socioeconomic costs. In 1999, torrential rains over the Niger River and its tributaries located in Benin and Nigeria, led to the opening up of the floodgates of the Kainji, Jebba and Shiroro dams in Nigeria, resulting severe flash flooding which inflicted a heavy human death toll and considerable material loss. During the same year, floods over the Ghanaian portion of the White Volta River claimed tens of lives and destroyed hundreds of houses. After experiencing a devastating flood that resulted in the displacement of several hundred thousand people in 1998, the Komadugu Yobe Valley (Northern Nigeria) was flooded again in 2001: the death toll was over 200, with over 35,000 displaced environmental refugees. Such numerous example have more or less becomes part of the usual décor of the climate of this part of West Africa.

\section{Intensified Competition and Conflicts}

The drop in water availability or the degradation of its quality (due sometimes to climate change and variability) often resulted in exacerbated competition for access to water. The high degree of water interdependence of the countries in the region with regard to water (many international rivers), combined with the poor sensitisation of decision makers and the general public on the impacts of climate, is conducive to tension and even conflicts among states over water resources. Potential conflict areas include the lower half of the Niger River and the Volta Basin. Other consequences of climate change and variability such as devastating floods, the proliferation of floating weeds along watercourses, the deterioration of water quality, etc. are likely to contribute to straining relations between countries in the region. Thus, the basins face severe climate perils. Significant impacts have already been recorded. Therefore, worst-case scenarios can be expected if the climate variations observed in the recent decades continues or increases.

\section{Extreme Events}

Extreme events (devastating floods, droughts and sharp temperature changes) characterize climate change and variability, and seem to occur more frequently in West Africa. They sometimes entail very high environmental and socioeconomic costs. In 1999, torrential rains over the Niger River and its tributaries located in Benin and Nigeria, led to the opening up of the floodgates of the Kainji, Jebba and Shiroro dams in Nigeria, resulting in a heavy human death toll and considerable material loss. During the same year, floods over the Ghanaian portion of the White Volta River claimed tens of lives and destroyed hundreds of houses. After experiencing a devastating flood that resulted in the displacement of several hundred thousand people in 1998, the Komadugu Yobe Valley (Northern Nigeria) was flooded again in 2001: the death toll was over 200, with over 35,000 displaced people. More recently, in January 2002, heavy torrential rains accompanied by a cold wave affected southern Mauritania and northern Senegal, leading to the loss of dozens of human lives and decimating more than 50,000 cattle and 500,000 small ruminants. Such numerous examples have subsequently been part of the usual décor of the West African cli- 
mate. Thus, the West Africa region faces severe climate perils. Significant impacts have already been recorded. Therefore, worst-case scenarios can be expected if the climate variations observed in the recent decades continue or increase.

\section{Socio-Economic Impacts}

Climate variability and change directly affects West African national economies in general and those of the Sahelian States in particular. Three main reasons account for the above situation: (a) the significant contribution of rainfed agriculture to the sub-region's economy; (b) the poor status of water mangement; (c) the poor replenishment of reservoirs on which some countries depend heavily for the generation of hydropower and supply to industry and households. The city of Ouagadougou, which is supplied from impoundments, experienced severe supply shortfalls in 2002 and 2003. In February 1998, Ghana was faced with a severe energy crisis as a result of the drop in water level in Lake Volta, which sometimes falls below the required threshold for feeding the turbines of the Akosombo dam. This dam, together with the more modest ones such as Kpong, accounts for $95 \%$ of Ghanaian electricity consumption. Due to these various reasons, it is hardly difficult to observe that at the regional level, a significant correlation exists between annual rainfall and flow conditions on the one hand, and economic growth rates on the other hand.

In the agricultural sector, a reduction in the yield of the major crops is expected (maize, early and late millet, sorghum, rice, cowpea), and therefore a reduction in cereal production in particular [15]. The reduction of continental wetlands (Niger River Inland Delta and the Hadejia Nguru Wetlandes in the Lake Chad besin in Nigeria) combined with the decline in the rate of river flow would lead to the modification of the ecological niches and the life cycles of aquatic aspecies, fish in particular.

\section{Water Demand}

The total population of the Niger River Basin was over 106 million in 2000, with an average density of 31 peo $\mathrm{ple} / \mathrm{km}^{2}$. The degree of urbanisation in western Africa is expected to reach $65 \%$ by 2025 . To this end, individuals liv- ing in rural areas will have to produce enough food to meet their own needs as well as those of the growing urban population. Crop yields will also have to increase through intensified farming and the expansion of irrigated areas - both of which will place further pressure on freshwater resources. The Global Water Partnership [21] estimates that, per capita water consumption will be 100 litres per day in cities and 50 litres per day in rural areas, by 2025. Projections for water demand are based on population growth and the activities envisaged to be carried out under the country's development plans. Table $\mathbf{3}$ gives the water demand for some countries of Niger and Volta River Basins.

\section{Identification of Key Issues Arising from Climate Change}

Six western African countries are expected to experience water scarcity by the year 2025, namely Benin, BurkinaFaso, Ghana, Mauritania [15], Niger and Nigeria. Most of the other countries are now also constrained by inadequate water supply. Climate change scenarios predict reduced rainfall and increases in evaporation in most parts of the region. More specifically, an increase in the rate of desertification is predicted for the Sahelian zone. Countries in the coastal zone are expected to experience more intense rainfall and increase in runoff. If this prediction is combined with the existing high rate of deforestation and degradation of ecosystems, this could have serious consequences on soil erosion and consequently on agricultural production and food self-sufficiency.

The drop in water availability or the degradation of its quality exacerbated by climate change often resulted in intense competition for access to water. The high degree of interdependence of West African countries with regard to water (with many international rivers), combined with the poor sensitisation of decision makers and the general public on the impacts of climate, is conducive to tension and even conflicts among states over water resources. Potential conflict areas include the lower half of the Niger River and the Volta Basin. Other consequences of climate change and variability -- devastating floods, the proliferation of floating weeds along watercourses, the deterioration of water quality, etc. are likely to contribute to straining relations between West African countries.

Table 3. Water Demand of the Volta River Basin $\left(x 1^{6} \mathrm{~m}^{3}\right)($ Compiled from Country Reports, $[22,23,15]$

\begin{tabular}{|c|c|c|c|c|c|c|c|c|c|c|c|c|}
\hline Country & \multicolumn{3}{|c|}{1990} & \multicolumn{3}{|c|}{2000} & \multicolumn{3}{|c|}{2010} & \multicolumn{3}{|c|}{2020} \\
\hline Burkina Faso & 67 & 43 & 37 & 85 & 203 & 46 & 106 & 384 & 61 & 132 & 384 & 61 \\
\hline Côte d'Ivoire & - & 19 & 1 & 4 & 57 & 2 & 5 & 166 & 3 & 12 & 166 & 3 \\
\hline Mali & 5 & 126 & 4 & 9 & 180 & 37 & 13 & 219 & 74 & 16 & 219 & 74 \\
\hline Togo & 51 & 43 & 15 & 68 & 50 & 19 & 92 & 91 & 22 & 123 & 91 & 22 \\
\hline Total & 261 & 458 & 115 & 500 & 1603 & 224 & 744 & 3,956 & 334 & 1003 & 3,956 & 334 \\
\hline
\end{tabular}

D/I= Domestic/Industrial; I = Irrigation L = Livestock. 
Significant areas of mangroves and coastal wetlands will also disappear as a result of the accelerated sea-level rise anticipated by the climate scenarios. In countries such as (Senegal, The Gambia) and Nigeria, some studies estimate that all the mangrove areas will be decimated in the event of a rise in sea level of $1 \mathrm{~cm}$ per annum. The loss of the coastal wetlands and the mangroves, among other things, will affect the local economy, which depend on it (case of oyster fishing) and will disturb the migration cycle of millions of migratory birds. Sea encroachment will also result in the increase in salinization of soils, ground water and surface water in the coastal countries of the region.

At the international level, the high degree of interdependence of the West African countries with regard to water, combined with the low level of sensitisation of decision makers and public opinion on the impacts of climate, creates a favourable ground for tension and even inter-state conflicts over water resources. For example, Nigeria which has invested heavily in irrigation schemes and hydro-electric development in the downstream part of the river Niger (Kainji and Jebba dams, 1.6 million hectares of irrigated land, river transport installations, and urban water supply), fears today that the realization of dam projects upstream (Kandadji in Niger and Taoussa in Mali) would lead to a significant fall in the flow of the river in its Nigerian segment.

\section{CONCLUSIONS}

The series of droughts that affected the Sahel zone of the West Africa over the past three decades and the inconsistency exhibited by global climate models have generated great uncertainty about its distribution and prediction in time and space. First, the decrease in rainfall has in some parts of the Sahel translated into severe water stress and shortages, the accelerated desertification process, major crises in cereal production and massive migration of rural populations to urban centres, amongst others. The Permanent Interstate Committee for Drought Control in the Sahel (CILSS) was created in 1973 in response to this situation. The adoption of the United Nations Action Plan on Desertification in 1977 and the entry into force of the United Nations Convention on Desertification in 1996 resulted mainly from the Sahelian crisis. Since 2004, the African Monsoon Project (AMMA) of intensive and extensive research aimed at tackling the uncertainties surrounding rainfall prediction in West Africa and indeed West and Central Africa was undertaken. It has been noted that the rainfall of the West Africa region was becoming unpredictable without proper monitoring of upper air for adequate and revealing data.

In most cases, the climate change scenarios used do not consist of definite predictions but rather present plausible future climates. Considering the many possible future scenarios, what matters is the ability to manage the uncertainty. This includes reducing current vulnerability to climate variability and change as well as keeping management options open to deal with the worst-case scenarios and to take advantage of opportunities that may arise.

Apart from the uncertainties and complexities in the climate change research process, there also uncertainties associated with the impacts of future climate changes on water resources. This is because such impacts will depend on many non-scientific factors, including regional demographic fac- tors, water policies, prices and rules for operating complex systems [24]. Such factors can help systems cope with possible climate changes or they can make the system more vulnerable. Furthermore, we cannot know how or whether water managers will react in advance, or even if they will, the ultimate impact of climate change will depend on the choices and value judgement as well as scientific information and data. Unfortunately, lack of reliable and adequate data in the region have further complicate the matter and increase the uncertainties. For instance, since its entry into force in August, 1984, parties to the Abidjan Convention have, with UNEP's assistance, undertaken a number of activities including the development of programmes for marine pollution prevention, monitoring and control in cooperation with e.g. IMO, FAO, UNIDO, IOC-UNESCO, WHO and IAEA. However, despite all the efforts made in the implementation of the Abidjan Convention, a certain degree of uncertainty still prevails in assessing the pollution load in general, because of the paucity of reliable, detailed and historic scientific data on coastal, marine and freshwater environments in the region. There is an urgent need for precise qualitative and quantitative assessment of the significant sources of landbased pollution. Similarly, no data on the impact of climate change exist in the region on its extensive coastal zone. Therefore, no measures have been taken in order to prevent the effects of sea level rise. This paper has synthesized the state of art research regarding climate change impact on water resources in West African sub-region using the cases of three major basins of Senegal, Niger and Volta basins.

\section{REFERENCES}

[1] Ayibotele NB. Regional Hydrology and Water Resources in the African Humid Tropics. In: Bonell M, Hufschmidt MM, Gladwell JS, Eds. Hydrology and Water Management in the Humid Tropics, Cambridge: Cambridge University Press 1993; p. 590.

[2] Le Barbe L, Lebel T. Rainfall Climatology of the HAPEX-SAHEL region during the years 1950-1990. In: Goutorbe JP, Dolman AJ, Gash JHC, et al. Eds. Elsevier, HAPEX-SAHEL, 1997; pp 1079.

[3] Hulme M, Doherty R, Ngara T, New M, Lister D. African climate change: 1900-2100. Climate Res 2001; 117, 145-68.

[4] Sehmi NS, Kunzewicz SW. Water, Drought and desertification in africa. In: Sustainability of Water Resources under Increasing Uncertainty. Proceedings of Rabat Symposium SI, April 1997.

[5] IPCC: Impacts, Adaptation \& Vulnerability. Contribution of Working Group II to the Third Assessment Report of the Intergovernmental Panel on Climate Change (IPCC) James J, McCarthy of, Canziani NA, Leary DJD, Kasey SW, Eds. UK, Cambridge University Press, 2001; p. 1000.

[6] Brooks N, Di Lernia S, Drake N, et al. The environment-society nexus in the Sahara from prehistoric times to the present day. North Afr Stud 2005; 304, 253-92.

[7] Brooks N. Drought in the African Sahel: long-term perspectives and future prospects. Tyndall Centre Working 2004; p. 61.

[8] Claussen M, Brovkin V, Ganopolski A. Climate change in northern Africa: the past is not the future. Climatic Change 2003; 57: 99118.

[9] Maynard K, Royer JF, Chauvin F. Impact of greenhouse warming on the West African summer monsoon. Clim Dyns 2002; 19: 499514.

[10] Wang GL, Eltahir EAB. Impact of $\mathrm{CO}_{2}$ concentration changes on the West African summer monsoon. Clim Dyn 2002; 19: 499-514.

[11] Anyamba A, Tucker C J. Analysis of Sahelian vegetation dynamics using NOAA-AVHRR NDVI data from 1981-2003, Arid Environ 2005; 63: 596-614.

[12] Olsson L, Eklundh L, Ardo J. A recent greening of the Saheltrends, patterns and potential causes. Arid Environ 2005; 63: 55666.

[13] IPCC: Climate Change: Impact, Adaptation and Vulnerability. Contribution of Working Group II to the Fourth Assessment Report 
of the Intergovernmental Panel on Climate Change, Parry ML, Canziani OF, Palutikof JP, van der Linden PJ, Hanson CE, Eds. Cambridge UK, Cambridge University Press 2007; p. 976.

[14] OMVS: Analyse Diagnostique Environnementale Transfrontaliere du Bassin du Fleuve Senegal. Project FEM/Bassin du Fleuve Senegal 2007; Composante 3.

[15] UNEP, WRC. Freshwater threat: Vulnerability Assessment of Freshwater Resources to Environmental Change-Africa 2008.

[16] Dai A, Trenberth, KE, Qian T. A global data set of Palmer Drought Severity Index for 1870-2002: relationship with soil moisture and effects of surface warming. J Hydromet 2004; 5: 1117-30.

[17] Oyebande Lekan, Amani Abou, Mahé Gil, Diop Isabelle Niang: Climate Change, Water and Wetlands in West Africa: Building linkages for their Integrated Management. Special Commissioned Paper. IUCN-BRAO. Ouagadougou. April 2002.

[18] UNEP, Abe J, Wellens-Mensah J, Diallo OS, Mbuyil Wa Mpoyi C. Guinnea Current, Global International Waters Assessment
(GIWA). Regional assessment 42 University of Kalmar, Kalmar, Sweden 2004.

[19] IPCC: Climate change and Water, Technical paper of the Intergovernmental Panel on Climate Change IPCC, Bates BC, Kundzewicz ZW, Wu S, Palutikof JP, Eds. IPCC Secretariat; Geneva 2008; p. 210.

[20] SEDEC ASSOCIATES: Federal Ministry of Environment, Housing and Urban Development. State of the Nigerian Environment Report 2008.

[21] GWP/WATAC. West African Water Vision. GWP/Technical Advisory Committee (TAC). Water Forum Papers 2000.

[22] WARM, Information Building Block, Part, III, Water Res 1997; Vol. 1.

[23] UNEP: Some Technical Information and country Reports, 2001, United Nations 2001.

[24] Gleick PH. Making Every Drop Count. Sc. America, February, 2001; pp. 28-33.

Received: January 05, 2010

(C) Oyebande and Odunuga; Licensee Bentham Open.

This is an open access article licensed under the terms of the Creative Commons Attribution Non-Commercial License (http://creativecommons.org/licenses/by-nc/3.0/) which permits unrestricted, non-commercial use, distribution and reproduction in any medium, provided the work is properly cited. 